\title{
Features of the Use of Lean Logistics Tools in Agricultural Regions
}

\author{
Irina Chistnikova \\ Department Department of Applied Economics and Economic \\ Security \\ National Research University "Belgorod State University" \\ (BelSU) \\ Belgorod, Russia \\ chistnikova@bsu.edu.ru \\ Filipp Ermachenko \\ Department Department of Applied Economics and Economic \\ Security \\ National Research University "Belgorod State University" \\ (BelSU) \\ Belgorod, Russia \\ yermachenkof@mail.ru
}

\author{
Irina Gunter \\ Department of Finance and Customs Revenues \\ Belgorod University of Cooperation, Economics and Law \\ Belgorod, Russia \\ ira19792000@mail.ru
}

\begin{abstract}
The article is devoted to the development of proposals for improving the activities of agricultural enterprises, based on the philosophy of lean logistics, to increase productivity. The use of a logistic approach in agriculture can contribute to a significant reduction in the cost of agricultural products, the development of individual farms and the country's agro-industrial complex as a whole. The article discusses the content and features of lean logistics in crop production, taking into account the factors of seasonality and the relationship between production and biological processes. A Lean Logistics methodology has been developed that allows you to manage and organize logistics operations in the supply chain at three levels, such as supply, storage and distribution of agricultural products, to identify and eliminate non-value added activities. The procedure for managing the logistics process of crop production at all its stages is presented: inventory management, procurement management, raw material warehouse management, finished product warehouse management. The goals and content of each stage are determined. The proposed recommendations are aimed at optimizing logistics in crop companies in order to increase productivity, reduce losses and minimize the cost of moving and storing agricultural products. Lean logistics activities can help reduce unnecessary steps and standardize crop production processes.
\end{abstract}

Keywords - lean logistics, logistic process, warehousing, crop farming.

\section{INTRODUCTION}

To maintain profitability and competitiveness in international markets, farmers must reduce costs by increasing process efficiency.

The organization of resource provision for agricultural producers has a significant economic, social and environmental effect. Therefore, using a logistic approach, it is possible to identify and solve key problems in the agricultural sector, while the use of lean technologies gives a high effect without significant material costs.

Identifying and modifying inefficient logistics operations and functions can dramatically improve the position of agriculture around the world.

Currently, the existing logistics at all stages of the technological process of growing, processing and delivering food products to the consumer is extremely ineffective $[3,15$, 21].

Crop farms often have inefficient storage methods leading to product losses; numerous product sorting and reloading, as well as costly multi-link delivery system and associated energy, labor and product losses.

Many agricultural organizations lack a logistics management process. This practice leads to a decrease in the profitability of agricultural producers.

Also the reason for the shortcomings in the management of logistics in crop production is the lack of analysis of key indicators and costs. At the same time, manufacturers do not apply a system of standardized processes, create a large workload and do not take full advantage of the benefits of their activities.

Analysis of logistics systems in the agro-industrial complex indicates the need to improve them using modern approaches and tools of lean production.

It should be noted that today there is a need to develop a methodology for creating lean logistics in crop farms to optimize delivery, storage and distribution processes, identify and eliminate actions that do not add value, in order to minimize logistics costs. 


\section{METHODS}

The research materials were the scientific works of economists in the field of lean technologies, practical measures, priorities and principles of applying lean technologies.

Achievement of this goal was based on the principles of dialectical objectivity, positive and normative approaches, induction and deduction. A systematic approach to the generalization of the set of tools for lean technologies in agriculture, as well as an expert method and logical analysis are used to substantiate the need to apply the lean concept in the activities of crop enterprises.

\section{MAIN PART}

\subsection{Lean Logistics content in crop production}

Crop logistics studies the material flows that support the main production process of an agricultural organization. The peculiarity of the logistics of plant growing organizations is expressed in the fact that the production and biological processes are closely intertwined, material flows can be of a biological nature [14, 18].

The pronounced seasonality inherent in crop production leads to the need for long-term storage of stocks of both finished products and raw materials (seeds). Material flows in agriculture change significantly when moving towards the end consumer. At the same time, changes in the properties of the material flow lead to changes in the requirements for storage of products: temperature, humidity, gas environment, shelf life. This, in turn, makes it necessary to have specialized storage facilities, transport and places of sale.

Improvement of zonal farming systems and technologies, based on the laws and principles of system logistics, allows you to increase the yield, gross collection of environmentally friendly products, significantly reduce production costs, correctly, mutually beneficial to build relationships between producers, processors and consumers, to ensure the protection of the natural environment $[16,23,28]$.

The main task of logistics in agriculture is to solve the problem of maintaining high quality characteristics of the harvested crop while organizing its storage and delivery to processing centers. The solution to the problem is significantly complicated by the nature of the feed stream being moved. Crop products are damaged during transportation.

Lean Logistics is a set of methods and tools aimed at creating a pull system in the overall logistics chain, but with an emphasis on optimizing and improving procurement and inventory management processes, including transport and warehouse logistics [2, 19, 24].

The main result of the implementation of Lean technologies is the optimization of the total logistics cost in the supply chain with a simultaneous increase in the "delivery" indicator (delivery discipline - complete and on time) $[4,9,10,12,17]$.

For the effective use of logistics in agriculture, it is necessary to detail the processes of logistics systems.

At the level of an individual enterprise, it is necessary to assess the efficiency of supply, production and marketing of finished products, as well as the relationship between these functions. The main focus should be on optimizing internal flows in order to solve the problem of the isolation of production sites and agricultural areas in space.

One of the directions for optimizing logistics processes should be their standardization based on the analysis of the supply chain, storage and receipt of resources, as well as the analysis and control of costs and production indicators of an agricultural producer.

To organize a lean logistics system in agriculture, it is necessary:

- the establishment of pull production, that is, the choice of volumes of activity based on the size of the order of the next link;

- alignment both at each stage, and in general along the value stream;

- organization of a system of frequent shipment in small batches;

- organization of intermediate storage points for cargo consolidation along replenishment cycles [24, 27].

The pulling method is a system in which parts and semifinished products are fed to the subsequent technological operation as needed, therefore there is no rigid centralized schedule, that is, this system is based on the decentralized principle of material flow management $[5,16]$.

\subsection{Process steps logistics management}

The structure of the logistics management process can be divided into three stages: procurement management, inventory and warehouse optimization. At each stage of the logistics process, it is advisable to introduce lean manufacturing tools to eliminate all types of losses.

The development of an algorithm for the use of lean logistics tools in agricultural farms should begin with an inventory $[1,8]$.

It is necessary to analyze the resource requirements, the amount of stock in the warehouse and draw up a procurement plan based on the rationing system [20].

At the stage of inventory management, it is important to ensure the continuity of logistics processes, which is related to the amount of maintained stocks, as well as their productivity. Purchasing processes have a huge impact on the inventory of materials in the operational process, and the sales process affects the inventory of finished goods. This sub-process initiates all logistics management.

Logistics of stocks of an agricultural enterprise is a single process that ensures operations with stocks both inside the company and outside it, at all stages of their delivery to the end consumer [22].

This stage of agricultural work is the initial one, it is carried out from the moment the materials are entered. In accordance with this, the stock of input raw materials is checked, if there are stocks, appropriate annotations are made of what is found and registered; otherwise, the required quantity is analyzed using the production plan and a procurement plan is drawn up, which will be sent to the procurement sub-process.

It should be noted that the stages of inventory management and storage of finished products are consistently interconnected [6]. 
The main tasks of inventory logistics are as follows:

- Planning - calculating optimal stocks for the future period, determining an acceptable budget, and calculating the timing and amount of purchases.

- Timely regulation - maintaining inventory at the required level to ensure the smooth operation of the enterprise.

- Accounting and control - drawing up an accounting report, as well as monitoring the movement of products in order to timely identify surpluses and shortages.

- Analytics of the use of stocks - an assessment of the occurrence of costs and the formation of stocks will allow timely adjustments to the strategy of purchasing and selling products.

According to the report generated for stocks and selected suppliers, purchase orders should be executed, delivery times and orders should be agreed upon.

All incoming goods in good condition should be accepted for storage at the plant's warehouse, raw materials that do not meet the established quality requirements should be returned to the supplier.

Stage - procurement management begins with obtaining a raw material procurement plan and selecting suppliers. They are analyzed in accordance with the requirements of the supplier and the product, which have been determined by quality management, and the one that is best suited is selected.

After selecting a supplier, the delivery date is agreed, if the supplier is approved, the delivery date is agreed, the procurement and delivery schedule is executed, which is registered at the warehouse and a purchase order is issued.

On the other hand, if the supplier is not admitted, the process is repeated from the supplier search.

At the stage of procurement optimization, it is recommended to compile a database of suppliers and analyze the interaction with each of them. Particular attention should be paid to the quality of products and raw materials. The most essential in "lean logistics" is the relationship with trusted and reliable suppliers [7].

At the warehouses of raw materials and finished products, it is necessary to check the storage and processing methods, including the preservation of the quality characteristics of the products and the regularity of sanitary measures.

It should be noted that all stages of the logistics process of a plant growing company are interconnected.

Stage - warehouse management for the storage of raw materials, materials and accessories required for agricultural production begins with processing the delivery schedule.

Then the input data is validated and recorded and stored according to storage standards that ensure quality.

Likewise, if the item was delivered in poor condition, the order is returned, this is communicated via a return document.

Stage - management of the finished product warehouse begins after harvesting. Finished agricultural products are checked for quality compliance and transferred to the warehouse in accordance with storage standards. Substandard finished products are classified as waste and written off [24].

\subsection{Probabilistic Automata}

For the correct organization of the management of the logistic process of crop production, it is necessary to determine its main parameters. Control elements of the logistic process of crop farming are presented in Table 1.

To organize work and ensure the efficiency of operational actions in the warehouse economy of agricultural organizations, the following principles of lean production should be applied:

- reduction of stock storage volumes. The development of an operating strategy for inventory can significantly change the quantity and structure of inventory. Knowing the levels of minimum and maximum storage, as well as points of additional order will give a clear picture of the presence of excess stock and help to model the required storage areas;

- reduction in the number of warehouse operations. The more time it takes to process one unit of goods, the more expensive it is. The first step is to eliminate duplicate functions. It is necessary to investigate in detail all the operations performed by employees and exclude unnecessary actions (filling out magazines, drawing up documentation at the request of the accounting department). Receipt and acceptance of goods is one of those processes that must be performed one-time. A system in which an employee receives materials and, according to the list, sends them for placement, and then gives this list for data updating, ineffective and outdated;

- transfer of operations to the early stages. The efficiency of logistics operations can be significantly increased if part of them is transferred to the previous stages. For example, if the goods are shipped from warehouse to warehouse, then the packaging may already have a universal marking, which is used in both warehouses, which eliminates the need to recount and label the packaging. Or, for example, materials that enter the warehouse are tagged before they leave production in order to facilitate future processes;

- identification and tracking of goods. The direction of warehouse optimization should be the use of a proper information management system. Lean workers need to know exactly where the materials are stored and not spend a lot of time searching for a particular item. One of the directions for creating a lean warehouse is a system for standardizing the space where goods are stored;

- optimization of the arrangement of racks and the use of warehouse space. It is advisable to use modern multilevel storage systems and effective arrangement of shelving, eliminating unnecessary transportation;

- use of algorithms for collecting goods. An efficient warehouse must be designed and organized in such a way that it meets the needs of the farm. This is important in order to avoid losses for moving around the warehouse. It is necessary to think about how many trips employees make when collecting an order for shipment, and how to organize the premises so as to reduce the number of movements;

- optimization of storage places for goods. In the area closest to the shipping area, it is necessary to locate the goods with the highest order frequency. The principle of joint storage of "travel goods" should be observed. Materials that 
have been ordered and brought together must be stored in the same way;

- increasing the reliability of collecting goods for order. When collecting the wrong materials, the warehouse has losses not only for the return of the purchase, but also for the return of stock to the place. The use of automatic systems for checking and preventing shipment in the event of a discrepancy between the barcode of the goods or the information in the invoice, should give more reliability and controllability to the actions performed. Well, every mistake should be analyzed and implemented in order to prevent repetition in the future;

- loading the goods in reverse order to the unloading sequence. With regard to these operations, the machines must be loaded in reverse order so that the last part is the first to be unloaded. This will improve the efficiency of subsequent stages of the logistics chain;

- shipment planning. Knowing the sequence of shipments will allow you to better optimize the operation of loaders and their loading (preparing goods for several machines at once, shipped in the next hour). Standardization of actions when preparing a machine for loading means not only the exact time of the operation, but also all the actions that can be performed before loading, thereby reducing the cycle of work performed when loading goods.

\begin{tabular}{|c|c|c|c|c|}
\hline & \multicolumn{4}{|c|}{ Stages of managing the logistics process } \\
\hline & Inventory management & Procurement management & $\begin{array}{c}\text { Raw material warehouse } \\
\text { management }\end{array}$ & $\begin{array}{l}\text { Warehouse management for } \\
\text { finished products }\end{array}$ \\
\hline Stage goal & $\begin{array}{l}\text { Inventory of stocks of raw } \\
\text { materials and finished } \\
\text { products in order to establish } \\
\text { their availability to ensure } \\
\text { business continuity }\end{array}$ & $\begin{array}{l}\text { Purchase of raw materials, } \\
\text { materials and accessories for } \\
\text { production }\end{array}$ & $\begin{array}{c}\text { Storage of raw materials, } \\
\text { materials and accessories for } \\
\text { production }\end{array}$ & Storage of finished products \\
\hline Content of work & $\begin{array}{c}\text { - receiving requirements } \\
\text { (orders for raw materials) } \\
\text { - checking warehouse stocks } \\
\text { - preparation of accounting } \\
\text { documentation, if the product } \\
\text { is available } \\
\text { - calculation of stock } \\
\text { requirements } \\
\text { - drawing up a procurement } \\
\text { plan }\end{array}$ & $\begin{array}{l}\text { - search for suppliers of raw } \\
\text { materials } \\
\text { - analysis of parameters of } \\
\text { raw material suppliers } \\
\text { - selection of suppliers } \\
\text { - agreement on the delivery } \\
\text { date if the supplier is } \\
\text { approved; if not, keep } \\
\text { searching. } \\
\text { - ordering to the supplier }\end{array}$ & $\begin{array}{c}\text { - receiving the goods } \\
\text { - return of low-quality raw } \\
\text { materials (if necessary) } \\
\text { - taking orders } \\
\text { - placement of raw materials, } \\
\text { materials and accessories in } \\
\text { the warehouse }\end{array}$ & $\begin{array}{l}\text { - acceptance of finished } \\
\text { agricultural products } \\
\text { - sorting of finished products } \\
\text { - preparation of a waste } \\
\text { report } \\
\text { - storage of finished products } \\
\text { - preparation for shipment to } \\
\text { customers }\end{array}$ \\
\hline $\begin{array}{l}\text { Documents for } \\
\text { control }\end{array}$ & $\begin{array}{l}\text { Production plan, supply } \\
\text { requests }\end{array}$ & $\begin{array}{l}\text { Purchasing plan, } \\
\text { requirements for suppliers, } \\
\text { requirements for products }\end{array}$ & $\begin{array}{l}\text { Delivery schedule, storage } \\
\text { standards }\end{array}$ & Storage standards \\
\hline $\begin{array}{l}\text { Responsible } \\
\text { person }\end{array}$ & $\begin{array}{l}\text { Logistics and inventory } \\
\text { managers }\end{array}$ & $\begin{array}{l}\text { Logistics Manager, Quality } \\
\text { Manager, Purchasing } \\
\text { Manager }\end{array}$ & $\begin{array}{l}\text { Logistics manager, quality } \\
\text { manager, storekeeper }\end{array}$ & $\begin{array}{l}\text { Logistics manager, quality } \\
\text { manager, storekeeper }\end{array}$ \\
\hline
\end{tabular}

Optimization of the supply chain to improve its efficiency in agriculture is carried out in the following areas:

1. Reducing logistics costs by optimizing costs to ensure delivery with a given level of quality and labor productivity.

2. Increasing the level of warehouse service to ensure optimal customer service as the main competitive advantage of the company.

\section{Increase in labor productivity.}

Lean logistics tools are effective only when there is no chaos in their use, there is a detailed plan for using a particular tool, and there is an understanding of the effect of the action. Each tool must be used with caution, systematically, without the deployment of globalization, because in this case the resource base, especially human potential, loses its main idea, makes mistakes along the entire critical path of a lean logistics project.

Thus, the main results of Lean-logistics in agriculture should be:

- reduction of labor and time costs when moving tools, raw materials and materials within the enterprise itself and transporting products (cross-docking, consolidation of orders and minimizing the movement of empty vehicles during delivery, optimal choice of a vehicle, optimization of routes, packaging of products, etc.) ;

- optimal placement of products in the warehouse, minimization of warehouse stocks and reduction of warehouse space;

- guarantee of delivery of products to the customer (complete and on time);

- minimization of losses during transportation;

- continuous improvement of processes.

In any agricultural organization there will always be factors that put a lean logistics project at risk, so it is necessary to take them into account and take certain measures to counteract or prevent them.

The main threats in the implementation of a project to organize lean logistics in crop production are: the emergence of unplanned costs, lack of sufficient resources, failure to meet planned stages, insufficient motivation and resistance of personnel to new methods of work.

After identifying possible future problems, they are analyzed, which identifies the root cause and methods of neutralization. 


\section{CONCLUSION}

In general, the use of a logistic approach in agriculture can contribute to a significant reduction in the cost of agricultural products, the development of individual farms and the country's agro-industrial complex as a whole.

At the same time, lean logistics in crop companies requires clear coordination of the activities of all categories of personnel involved in the value stream - the main and auxiliary production workers, service and management personnel. Since lean logistics is a constant search for innovative solutions for the main business idea - reducing costs to increase the efficiency of activities and the quality of agricultural products.

The proposed directions for organizing lean logistics will help reduce unnecessary actions and standardize crop production processes. According to the risk matrix, the team is exposed to various events that can affect the effectiveness of the project. Finally, since the logistics process is an auxiliary process, the effect of lean logistics will largely depend on the company's comprehensive work on quality management and planning.

\section{REFERENCES}

[1] Yu. Adler, and G. Stasova, "Comparison between the Desirability Function by E. C. Harrington and the Loss Function by Genichi Taguchi", 10th ANQ Congress, Hong Kong, Proc. Hong Kong, 2012, pp. 977-983.

[2] M. Baudin, Lean Logistics: The Nuts and Bolts of Delivering Materials and Goods, NY: Productivity Press, 2004, 400 p.

[3] R.B. Chase, N.J. Equiline, and R.F. Jacobs, Production and operational management. Lane. with eng, Moscow: Williams, 2004.

[4] I.V. Chistnikova, M.V. Antonova, E.G. Serova, I.A. Skliarenko, and E.S. Alekhina, "Economic mechanism of functioning of the production system based on the use of lean technologies", Revista inclusiones. 7. Número Especial, 2020, pp.13-28.

[5] V.G. Denisova, "Visual management as a management tool", Standards and quality, 2019, no. 9, pp. 70-74.

[6] F.R. Galimova, and O.A. Khasanov, "Basis of logistics of agriculture", Actual Science, 2018, no 5 (10), pp. 43-45

[7] T.V. Glavatskaya, "The concept of lean logistics", Actual scientific research in the modern world, 2018, no 1-2 (45), pp. 73-78.

[8] D.T. Jones, P. Hines, and N. Rich. Lean logistics, International Journal of physical distribution \& logistics management, 1997.

[9] S.A. Kucheryavenko, I.V. Chistnikova, B.A. Thorikov, and A.N Nazarova, "Adaptation of lean production tools to educational activities of universities”, Revista Turismo: Estudos \& Práticas (UERN), 2019, no 2.

[10] S.A. Kucheryavenko, I.V. Chistnikova, S.A. Gayvoronskaya, and A.S. Glotova, Trends and scenario modeling of university educational process development through the use of lean manufacturing principles, Revista Turismo: Estudos \& Práticas (UERN), 2019, no 2

[11] A.M. Kuzmin, and E.A. Vysokovskaya, "Office for goals", Methods of quality management, 2012, no 3, pp. 11-12.

[12] E. Lander, and J.K. Liker, "The Toyota Production System and art: making highly customized and creative products the Toyota way", International Journal of Production Research, 2007, no 45 (16), pp. 36813698.

[13] P.Yu. Lapaev, "The use of key performance indicators in management by goals", Actual directions of scientific research: from theory to practice, 2015, no 1 (3), pp. 318-319.

[14] G.G. Levkin, O. A. Nakonechnaya, and K.O. Dzyubina, "Key problems in the logistics system of fruit and berry production", Innovative Economy and Society, Omsk: Omsk State Transport University, 2013, no 2. pp. 52-56.

[15] D.I. Lukashevich, "Technologies of "lean manufacturing" in enterprise management", Ural Scientific Herald, 2018, no 4, pp. 6-8.

[16] T. Melton, "The benefits of lean manufacturing: what lean thinking has to offer the process industries", Chemical engineering research and design, 2005,no 83 (6), pp. 662-673.

[17] A. Mossman, Lean logistics: Helping to create value by bringing people, information, plant, equipment and materials together at the workface,
International Group for Lean Construction. Michigan, EE. UU, 2007

[18] S. Mostafa, J. Dumrak, and H.A. Soltan, "Framework for lean manufacturing implementation", Production \& Manufacturing Research, 2013, no 1 (1), pp. 44-64.

[19] P. Myerson, Lean supply chain and logistics management, New York, NY: McGraw-Hill, 2012.

[20] V.A Pejić, "Review of contemporary lean logistics concept", Logistics systems in the global economy, 2016, no 6, pp. 50-54.

[21] J. Petersen, "Toyota way", Blackclick OH, USA. McGraw-Hill Publishing House, 2003, pp. 28-33.

[22] T.S. Pitel, "Problems and prospects of lean-technologies development in the sphere of agro-industrial complex", Bulletin of Agrarian Science, 2016, vol. 62, no 5, pp. 23-29.

[23] I.I. Setina, "Application of Lean Technologies in Organization Management", XX All-Russian Student Scientific and Practical Conference of the Nizhnevartovsk State University: collection of articles, 2018, pp. 149152.

[24] R. Shah, and P.T. Ward, "Lean manufacturing: context, practice bundles, and performance", Journal of operations management, 2003, no 21 (2), pp. 129-149.

[25] A. Thakur, "Review on Lean Manufacturing Implementation Techniques: A Conceptual Model of Lean Manufacturing Dimensions", REST Journal On Emerging trends in Modelling and Manufacturing, 2016, no 2 (3), pp. 62-72.

[26] J.P. Womack, and D.T. Jones, "Banish waste and create wealth in your corporation", URL: http://www. kvimis. co. in/sites/kvimis. co. in/files/ebook_attachments/James, 2003/(accessed 29.09.2020)

[27] A. Wronka, "Lean logistics", Journal of Positive Management, 2016, no 7.2 , pp. 55-63.

[28] L. Wilson, "How to implement lean manufacturing", New York: McGraw-Hill, 2010, pp. 45-197. 